\title{
Т.М. Яцків
}

директор Передплатного агентства «Укрінформнаука»

e-mail: innovation@nas.gov.ua

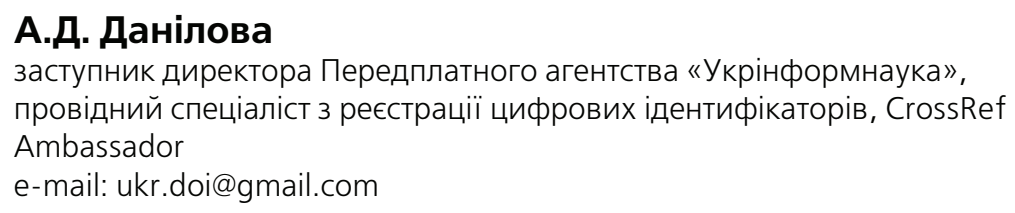

\section{ЗБІЛЬШЕННЯ КІЛЬКОСТІ ЗВЕРНЕНЬ ДО НАУКОВИХ ПУБЛІКАЦІЙ: CIM KPOKIB PA3OM I3 CROSSREF}

https://doi.org/10.15407/akademperiodyka.391.094

Розглянуто питання збільшення видимості наукових періодичних видань у міжнародному інформаційному просторі та кількості звернень до наукових публікацій за рахунок перехресних посилать. Описано інструменти і сервіси бази даних CrossRef: Metadata Manager BETA, Cited-by, реєстр організацій, які надають фінансування Funders to join Crossref as members. Зазначена важливість програми Initiative for Open Citations, головною метою якої $є$ поширення доступу до цитувань наукових публікацій. Описано можливості реєстру ідентифікаторів для організацій The Recearch Organization Registry (ROR).

Ключові слова: міжнародні наукометричні бази Web of Science i Scopus, цифрові ідентифікатори DOI, Агентство CrossRef, програма Initiative for Open Citations, Metadata Manager BETA, сервіс Cited-by, база даних, пошукова система.

Реалії сучасної наукової діяльності і органічно повязаної з нею публікації наукових журналів свідчать про тенденцію до збільшення широкого використання наукометричних покажчиків та індикаторів. Вважають, що об'єктивними критеріями оцінки ефективності діяльності дослідників $є$ кількість цитувань опублікованих ними статей (індекс цитування), імпакт-фактор (IF), Індекс Гірша ( $h$-індекс). Найвідоміші бібліометричні бази даних Web of Science (Science Citation Index) i Scopus - мають потужні інструменти для відстеження цитованості статей, опублікованих у наукових періодичних виданнях.

«При оцінці наукової продуктивності, на жаль, вдається вимірювати не те, що хотілося 6, а лише те, що можливо» - таку думку висловив у 1963 році британсько-американський історик науки Дерек Прайс, який 1946 року захистив дисертацію з експериментальної фізики в Лондонському університеті, а 1949 року - 
дисертацію 3 історії науки в Кембриджському університеті. Після цього захисту Прайс працював в США, спочатку в Смітсонівському інституті і Інституті перспективних досліджень США, а потім багато років був професором історії науки в Єльському університеті.

Прайс опублікцвав близько 240 наукових праць, серед яких найзначущою стала книга «Мала наука, велика наука» [1], що заклала основи сучасної наукометрии (рис. 1).

Прайс - один із найцитованіших авторів, на його роботи $є$ посилання, принаймні, у 2200 статтях. Книга «Мала наука, велика наука» набула особливої популярності. 3 усіх праць Прайса ця книга отримала найбільше посилань на неї посилаються 725 статей. Цитати знаходяться в журналах близько з 80 дісциплин, від $A$ (аеронавтика і антропологія) до $Z$ (зоологія), і звичайно, це роботи з інформатики і соціальних наук. Більш

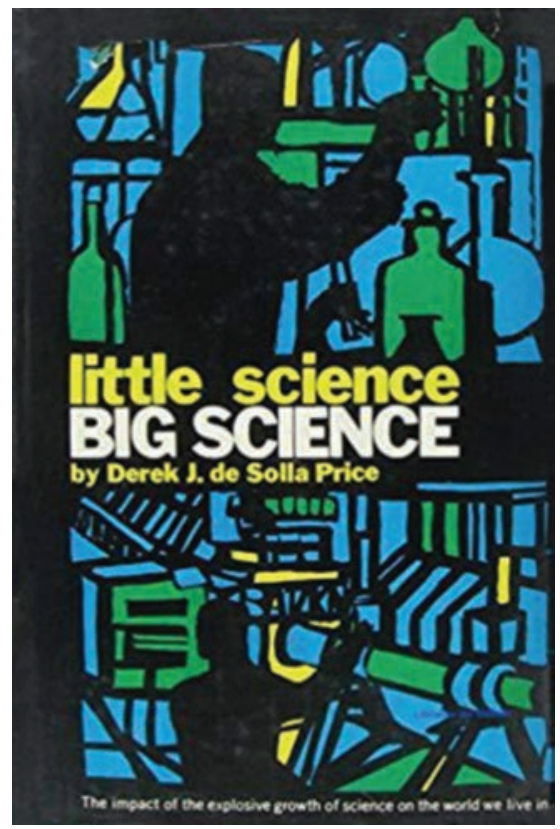

Puc. 1. Обкладинка книги Derek J. de Solla Price (1963). Little Science, Big Science. Columbia University Press, New York. 301 p. того, книга і сьогодні не втрачає актуальності. Зазвичай кількість посилань на наукову працю досягає максимуму в інтервалі від двох до п’яти років після опублікування. Кількість посилань на цю книгу продовжувала зростати протягом десятків років. Це призвело до того, що щотижневий огляд змісту наукових журналів Citation Classic Commentaries за поточним Current Contents позначив іiі як Citation Classic.

Метою діяльності наукових періодичних видань є збільшення кількісті цитувань опублікованих статей шляхом приведення журналів до міжнародних стандартів і критеріїв оцінки ефективності наукових публікацій [2]. Результатом цього є підвищення рейтингу журналу, наповненість його «портфеля» рукописами, можливість вибирати найактуальніші та найцікавіші матеріали для публікації.

База даних CrossRef. 3 метою збільшення видимості наукових публікацій за рахунок перехресних посилать було створено депозитарій наукових публікацій - базу даних CrossRef [3]. На сьогоднішній день депозитарій CrossRef налічує більше 105 мільйонів наукових обєктів, основна частина 3 яких (приблизно 80 \%) є публікаціями з журналів (рис. 2) [4].

Щомісяця депозитарій фіксує до 607 мільйонів запитів. Звернення відбуваються через пошукову систему (https://search.crossref.org/), яка є потужним інструментом пошуку будь-якої інформації: статистичних даних, обєктів, організацій, які надають фінансування, інституцій, дослідницьких рад, патентних відомств, видавців, центрів експертної оцінки, наукових публікацій тощо. 


\section{Crossref}

\section{Search the metadata \\ of $105,079,875$ journal articles, \\ books, standards, datasets \& more}

\section{Q Title, author, DOI, ORCID iD, etc.}

Puc. 2. Стартова сторінка для здійснення пошуку у базі даних CrossRef

\section{Dashboard}

Home $>$ Deshboard

Welcome to our new dashboard, a simple visual display of some of our key stats. And it's a work in progress. Aight now you can click on each number and all it does is take you to the same API query that calculated the figure (you'll need a json viewer).

Please contact us if you have some good ideas for building this out.

Numbers are updated hourty using our open REST APL, You can create your own visualizations of Crossref metadata too.
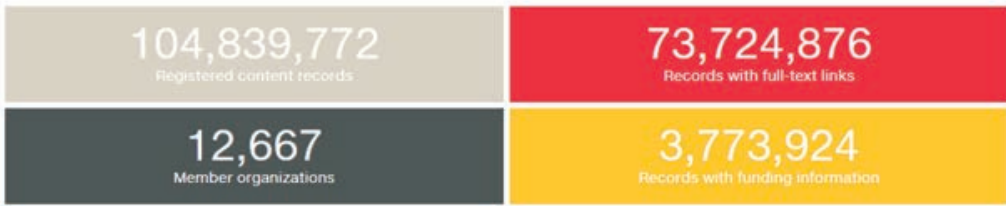

$2,662,827$

Records with a Funder Registry id

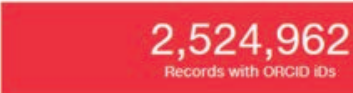

2,715

$35,497,224$

$8,751,032$

105,205

Puc. 3. Сторінка з автоматично згенерованими поточними статистичними даними CrossRef

Панель пошукової системи має візуально простий та зручний інтерфейс і автоматично демонструє деякі ключові статистичні дані (рис. 3). Робота над покращенням системи постійно триває. Дані системи оновлюються щогодини програмою REST API.

За допомою інструментів пошукової системи CrossRef можна отримати статистичні дані про видавців та окремі журнали (https://www.crossref.org/ participation/; https://www.crossref.org/members/prep/) (рис. 4). 


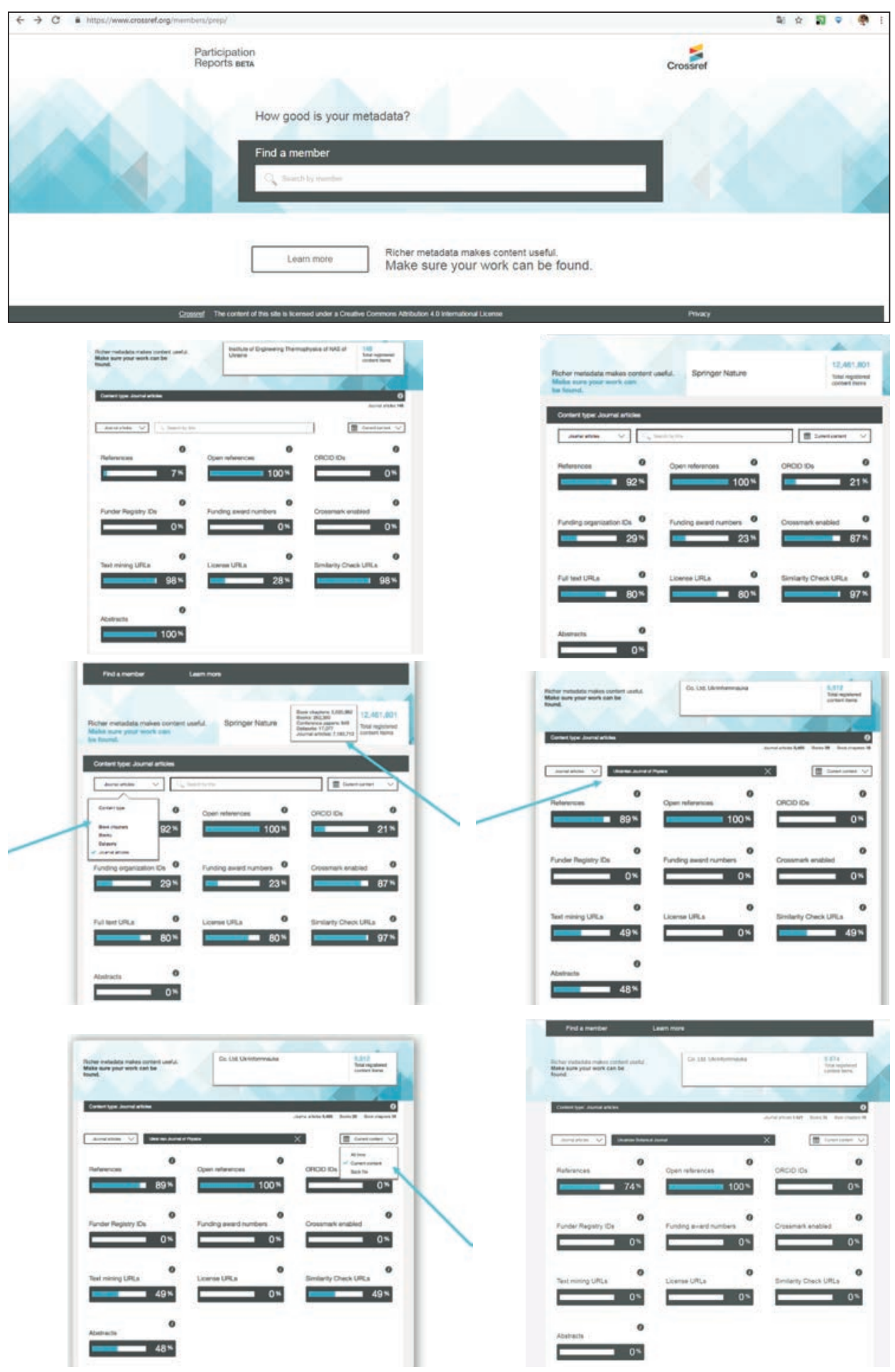

Puc. 4. Сторінки, що дають змогу здійснювати контекстний пошук за певними видами інформації у CrossRef 
Щомісячні звіти. На початку кожного місяця база данних CrossRef електронною поштою розсилає звіти зі статистичними даними про використання цифрових ідентифікаторів DOI за попередній місяць [5]. За замовчуванням звіти надсилають зареєстрованим членам організації PILA на електронні адреси контактних представників організації. За необхідності CrossRef може додавати або змінювати одержувачів. Звіти формуються окремо для кожного префіксу DOI, тобто для кожного видавця. На сайті Передплатного агентства «Укрінформнаука» [6] регулярно надається ця статистична інформація у вигляді $P D F$-файлів (рис. 5).

Звіт уміщує таку інформацію: частота звернень, частота невдалих спроб звернення (відсоток невдалих спроб звернення), частота відмов для певного префікса і загальна частота відмов (для всіх учасників Crossref), загальна кількість звернень у місяць за 12 останніх місяців за окремим префіксом і загальна кількість звернень (для всіх учасників Crossref). Також у звіті подається список десяти DOI з найбільшою кількістю успішних звернень за місяць, а також кількість, коли кожен індекс DOI був успішно використаний. Список невдалих спроб звернення до окремих DOI, перетворений на сторінку «Обробка помилок», представлено у вигляді файлу *.csv, прикріпленого до електронного листа звіту, він містить інформацію про відмови та кількість хибних звернень. Списки формуються за назвою публікації: кількість загальних звернень DOI на заголовок.

Cервіс Cited-by бази даних CrossRef [7]. Дослідники під час підготовки власної наукової статті посилаються на роботи інших науковців, формуючи пристатейні списки літератури, в яких перелічуються першоджерела, використані у ході роботи над рукописом. Безперечно, науковцям цікаво і корисно знати, в яких публікаціях цитується їхня власна стаття, як інші науковці заперечують або спираються на висловлені ними положення та ідеї.

Cepвic Cited-by допомагає учасникам дізнаватися, хто цитує їхній контент, і відображати кількість цитувань. Користувачі бази даних CrossRef для реєстрації власного контенту у вигляді метаданих передають у базу інформацію, на що й посилаються документи. Користувачі, які використовують цей сервіс, надають можливість науковцям легко переходити до матеріалів, пов'язаних із їхніми дослідженнями; побачити, наскільки конкретна робота була помічена спільнотою; а також дослідити, як висловлені ідеї розвиваються з плином часу, виявляючи зв'язки між роботами.

Учасники, які включають посилання на сервіс Cited-by в свої власні метадані, можуть вільно отримувати інформацію про цитування власного контенту. Крім того, цю інформацію можна розміщувати на домашній сторінці окремої статті на сайті наукового періодичного видання, наприклад, журнал New Journal of Physics (https://doi.org/10.1088/1367-2630/) розмістив таку інформацію у вигляді лічильника (рис. 6).

Активувати сервіс Cited-by дуже просто. Учасники в першу чергу повинні депонувати списки літератури до всіх статей, для яких були зареєстровані цифрові ідентифікатори DOI, і розмістити отримані посилання на власному ін- 

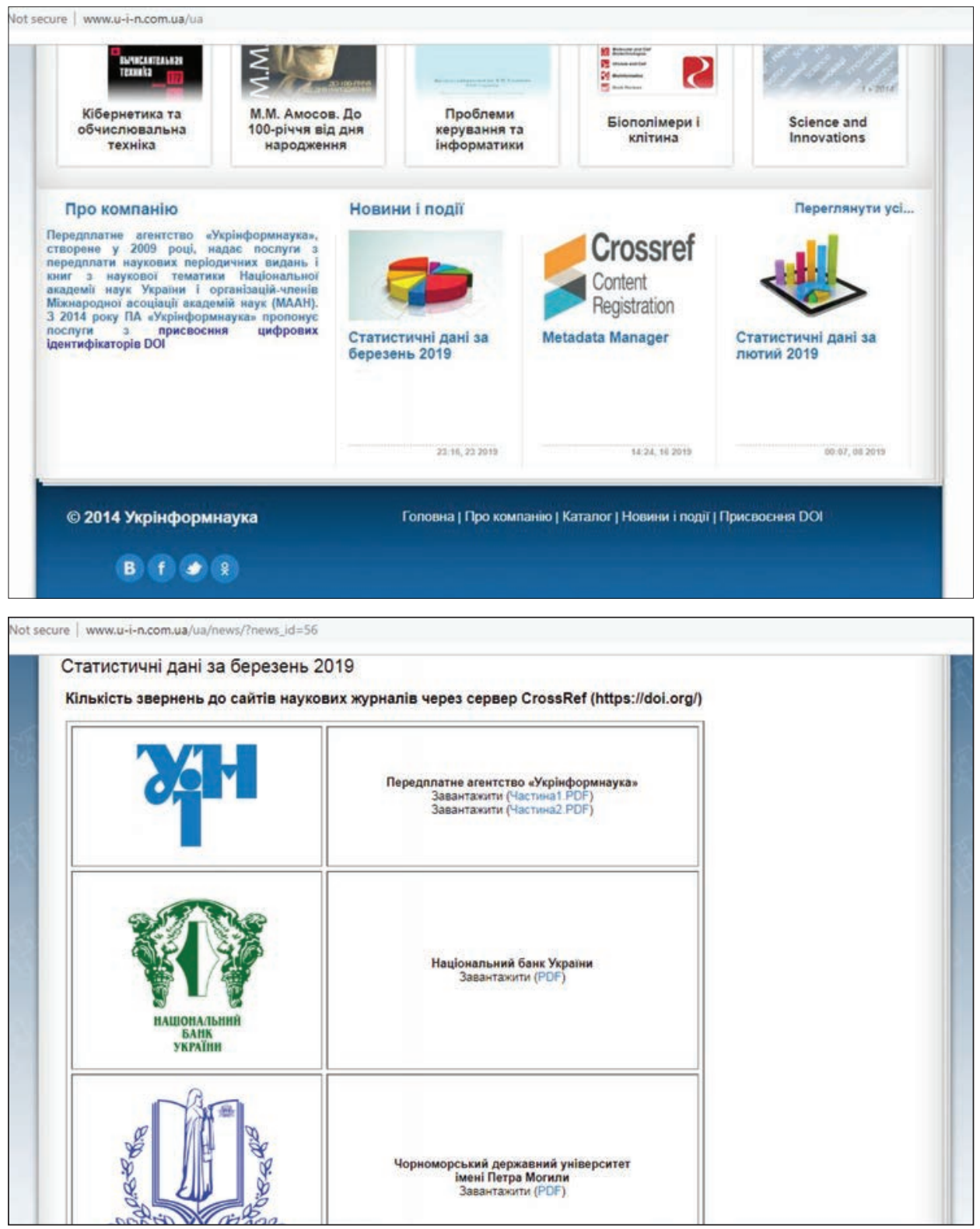

Puc. 5. Сторінки сайту Передплатного агентства «Укрінформнаука» зі щомісячними статистичними звітами CrossRef стосовно вітчизняних наукових журналів

тернет-ресурсі у відповідному місці - у пристатейних списках літератури відповідної статті [8]. Після цього запрацює механізм перехресних посилань для зв'язку з іншими учасниками бази даних CrossRef. Списки літерутари поточного матеріалу повинні бути депоновані до процессу запиту даних. Член спільноти буде вважатися таким, що бере участь у процесі, одразу ж після початку депо- 


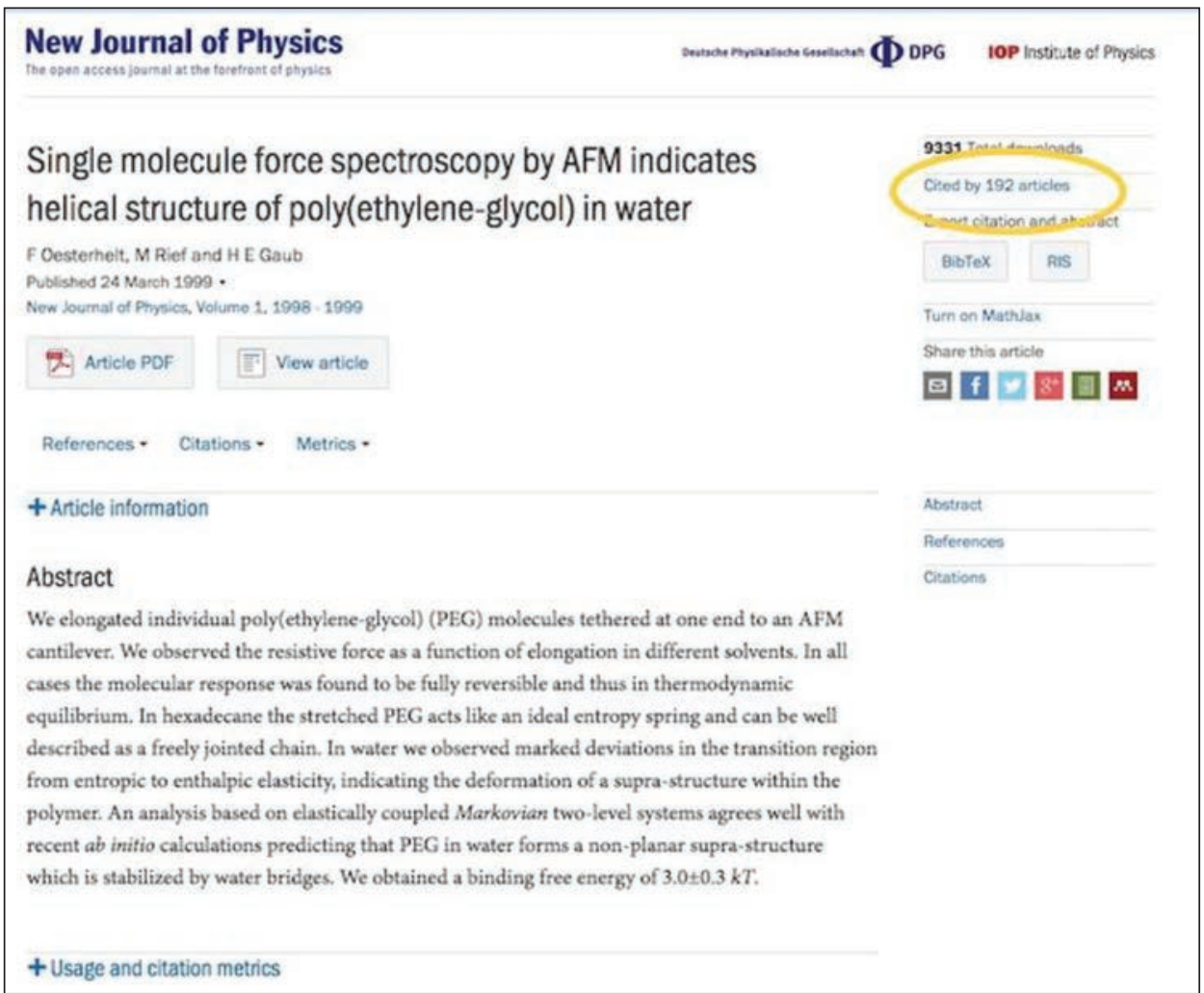

Puc. 6. Приклад розміщення на власному сайті інформації стосовно цитування вмісту наукового журналу

нування списків літератури. Члени спільноти можуть отримувати дані тільки для відображення в первинних статтях, які вони видають, для відображення на первинних платформах журналу чи в їх вторинних продуктах. Участь у програмi Cited-by не є обов'язковою, але вітається. І вона безкоштовна.

Усім учасникам бази даних CrossRef рекомендовано реєструватися i оновлювати максимально повні метадані, щоб зробити публікації доступними для перегляду і отримати максимальну вигоду з членства в Crossref. Метадані включають таку інформацію: назва журналу, прізвища всіх авторів статті, дата публікації, номери сторінок, ISSN журналу, анотації, ідентифікатори авторів статті ORCID, інформація про фінансування, номери клінічних випробувань, інформація про ліцензії, назви організацій, адреси сайту.

Депонувати дані в базу даних CrossRef і отримувати цифрові ідентифікатори DOI можна для багатьох типів матеріалів, пов'язаних із дослідженнями. Типи контенту, для яких нині можливо отримання ідентифікаторів, тобто які можуть бути депоновані в базу даних CrossRef:

1) журнали та журнальні статті: на рівні назви журналу та статті і додаткові матеріали до них; 
2) книги, розділи і довідкові матеріали: назви книг, назви розділів, монографії, серії книг;

3) матеріали конференції: інформація про конференцію і записи за кожним документом конференції / доповіді;

4) звіти / робочі документи: це включає в себе контент, який офіційно опублікований і зареєстрований з ISSN або ISBN;

5) стандарти: включає публікації організацій, які розробляють стандарти і нормативні документи;

6) дисертації: включає в себе окремі дисертації та тези;

7) препринти: складається з препринтів, друкованих видань, робочих документів, звітів та інших типів контенту, який був надрукований, але офіційно не опублікований;

8) рецензування: будь-яку кількість рецензій, звітів або коментарів, пов'язаних $з$ відповідною статтею;

9) компоненти: зазвичай прив'язуються до частин цілого об'єкта, найчастіше це малюнки, таблиці і додаткові матеріали для журнальної статті або глави книги;

10) гранти: для тих, хто фінансує дослідження, для реєстрації присуджених грантів, включаючи використання коштів або обладнання, винагороду і т. ін.

Зараз триває розробка схеми для можливості отримати цифрові ідентифікатори для грантів, конференцій і проектів.

Метадані можуть бути зареєстровані самими учасниками, уповноваженими представниками, що діють від їхнього імені, або власниками хостингових платформ. Контент може бути зареєстрований вручну або автоматично кількома способами.

Перший варіант депонування метаданих в базу CrossRef передбачає створення $X M L$-файлу відповідно до інструкції та завантаження його до системи CrossRef за допомогою програмних інтерфейсів.

Другий варіант - завантаження метаданих у ручному режимі з використанням Web Deposit Form (https://apps.crossref.org/webdeposit) - стандартний метод, яким користується більшість редакцій.

Третій варіант - використання вбудованого механізму передачі даних для журналів, інтернет-сайти яких розміщено на платформі Open Journal System (OJS), для якої Crossref створив окремий плагін. Цей метод дає змогу депонувати метадані без втручання людини. За умови, якщо плагін налаштовано для роботи в автоматичному режимі.

I нарешті зовсім новий спосіб - 3 використанням нового сервісу Metadata Manager. Він використовується для ручної реєстрації метаданих, підтримує як один, так і кілька депозитів у журналах, дає можливість використовувати кілька форматів і розмірів депозитів, автоматично перевіряє формат певних елементів метаданих і негайно обробляє поточні депозити в режимі реального часу.

Протягом 2018 року в діяльності CrossRef відбулися значні зміни, спрямовані на створення нових і розвиток та покращення роботи їі чисельних сервісів. 
1. Програма Initiative for Open Citations. Одним із важливих факторів підвищення видимості та рейтингу наукової публікації є перелік літератури, яку було використано науковцем чи групою науковців для підготовки матеріалів. 3 точки зору наукової цінності стаття буде вагомішою, якщо в ній $\epsilon$ посилання на новітні розробки й актуальні дослідження. Для того, щоб усі зацікавлені користувачі мали доступ до посилань на джерело, потрібна їхня повна відкритість і видимість у світовому інформаційному просторі. Навіщо потрібна відкритість списків літератури? На що вона впливає, окрім рейтингу публікацій? Чи вигідно це для науковців? У першу чергу, звичайно, це вигідно самим виданням, адже цей крок допомагає поширювати посилання усім зацікавленим користувачам, без обмежень, через всі служби доставки метаданих Crossref (Metadata Delivery Service), включаючи REST API та масові дампи метаданих. Списки літератури можна зробити доступними за умови, що публікація має цифровий ідентифікатор DOI та їі метадані занесено до бази даних CrossRef.

2017 року значну підтримку серед наукової спільноти отримала програма Initiative for Open Citations, головною метою якої є поширення доступу до цитувань наукових публікацій. Програму підтримали такі відомі видавці академічної літератури як Springer Nature, Wiley, Cambridge University Press i багато інших.

Варто зазначити, що неабияку роль для Initiative for Open Citations відіграють бази даних, і тут неможливо не згадати Crossref, адже їхня бібліотека нараховує понад 105 мільйонів документів. Організація Crossref 31 січня 2018 року започаткувала політику відкритих списків літератури, про що й було повідомлено усім партнерам на початку року. Одразу ж після запуску даної програми Передплатне агентство "Укрінформнаука», яка $є$ членом Crossref і пропонує послуги з надання DOI українським виданням від 2014 року, однією з перших внесла в списки видавців із відкритими списками літератури (Members with open References) журнали Національної академії наук України та усіх інших своїх партнерів.

2. Сервіс Metadata Manager. За допомогою Metadata Manager BETA можна депонувати метадані наукових публікацій із реєстрацією цифрових ідентифікаторів DOI для статей наукових журналів та списків літератури до них (https:// www.crossref.org/metadatamanager/). Це новий сервіс Crossref, у якому покращено користувацький інтерфейс і додано декілька нових форм для передання метаданих. Також цей інструмент дає можливість передавати заголовки іншому видавцю без будь-якого втручання з боку служби підтримки Crossref.

3. Сервіс реєстрації літератури зазнав у 2018 році значних змін, він став зручнішим і простішим для використання. Основною вимогою бази даних Crossref $є$ обовязкове розміщення на домашній сторінці статті інтернет-сайту наукового журналу посилань на першоджерела, які використовуються в пристатейних списках літератури, у вигляді повного формату цифрового ідентифікатора DOI. Саме завдяки цьому можлива робота механізму перехресних посилань між публікаціями. 
Додавати цифрові ідентифікатори DOI до пристатейного списку літератури може автор статті на стадії підготовки статті, якщо редакція журналу рекомендує або зобов'язує авторів здійснювати такий пошук. Інший спосіб - додавання посилання до списку перед реєстрацією метаданих за допомогою пошукової системи Crossref для окремих статей (https://search.crossref.org/References). Цей спосіб повільний і потребує багато часу.

Ще один спосіб отримання посилань із бази даних Crossref - це депонування метаданих за допомогою генерації XML-файлів. Він дуже ефективний, але потребує певних знань і підготовки. Найпростіший і найуживаніший спосіб отримання посилань - використання інструменту пошуку Crossref Simpler Text Query Form (https://apps.crossref.org/simpleTextQuery) під час депонування списків літератури. Форма простого текстового запиту (Simpler Text Query, STQ) допомагає користувачам отримувати наявні DOI для журнальних статей, книг і їхніх розділів, вставляючи скопійований список посилань у просте поле запиту.

Зміни відбулися саме для інструменту Simpler Text Query. По-перше, раніше на першій і другій сторінках форми для реєстрації для отримання довідкових посилань необхідно було вносити зареєстровану в базі даних CrossRef адресу електронної пошти. Нова форма для реєстрації дозволяє уникати дублювання.

По-друге, для реєстрації пристатейних списків літератури існувало обмеження кількості щомісячних довідкових посилань на одну адресу електронної пошти - до 5000 реєстрацій. Тепер місячний ліміт кількості повністю відсутній.

По-третє, скасовано обмеження на кількість знаків для однієї реєстраціi. Якщо раніше можна було обробляти список літератури, який містив не більше 30000 символів, то зараз повністю видалено обмеження за кількістю символів, і замість цього просто введено обмеження на кількість посилань в одному переліку - не більше 1000 посилань на кожну реєстрацію. На сьогодні найбільший список пристатейних посилань, який було зареєстровано базою данних CrossRef через форму STQ в одному поданні, налічував близько 750 джерел. Таким чином, можна вважати, що обмежень немає.

4. Організаціі, які надають фінансування (Funders to join Crossref as members). Деякий час тому CrossRef оголосила про новий проект із розробки ідентифікаторів для організацій, що надають фінансування, який буде підтримувати зв'язок із відповідними ініціативами бази профілів для науковців ORCID. Проект було реалізовано, тому зараз можна подати заявку на членство, щоб зареєструвати гранти, і після внесення їх у депозитну систему, призначити їм цифрові ідентифікатори DOI. Гранти охоплюють нагороди, використання матеріалів і устаткування, а також безліч інших видів підтримки досліджень. Планується повністю активувати проект до грудня 2019 року. Але вже наприкінці травня 2019 року у реєстрі Crossref Funder Registry зареєстровано 3806487 організацій, які надають гранти. 
Яким чином можна внести дані про організацію-спонсора до реєстру Crossref Funder Registry? Автори наукових публікацій вказують джерела фінансування своїх досліджень у своїх публікаціях. Видавці стандартизують ці метадані і відправляють їх до CrossRef. Після цього інформація стає доступною через пошук даних про фінансування. Можна вносити метадані про публікацію, додаючи до своїх звичайних даних для Crossref три додаткові позиції: назву спонсора, ідентифікатор спонсора та номер гранту. За внесення даних про організації, які надають фінансування, плата не стягується. Пошук даних про фінансування знаходиться у вільному доступі.

Існує багато переваг у наявністі прозорої інформації про те, хто фінансував дослідження і де вони були опубліковані. Організації-спонсори можуть відстежувати, де були опубліковані результати досліджень, на які було віділено гранти. Науково-дослідні установи можуть відстежувати опубліковані результати своїх співробітників. Видавці можуть аналізувати джерела фінансування для своїх авторів і забезпечувати дотримання прав спонсорів. Читачі і громадськість отримують вичерпну інформацію відносно того, хто фінансував дослідження і які отримано результати.

5. Ідентифікатор організацій. Сьогодні відсутня відкрита інфраструктура, яка б містила реєстр ідентифікаторів дослідницьких організацій та пов'язаних із ними метаданих. Команда спеціалістів організації Crossref брала активну участь у проекті створення реєстру ідентифікаторів для The Recearch Organization Registry (ROR, https://ror.org) [9]. База даних ROR планує надавати для кожної дослідницької організації у світі ідентифікатори, які є відкритими, сталими, зручними та унікальними. Крім того, $R O R$ розроблятиме відповідну систему метаданих для організацій і досліджуватиме сумісність із іншими ідентифікаторами через взаємопов'язані метадані. Інтеграція ROR 3 наявними системами та ідентифікаторами, які вже використовують ключові міжнародні спонсори та інші зацікавлені сторони, забезпечує новому реєстру важливу перевагу. Інформація про кожну організацію буде представлена в базі персональною сторінкою (рис. 7).

Загалом ROR матиме декілька функцій і можливостей. Ідентифікатори для організацій дослідницького співтовариства будут стійкими та матимуть формат, який відповідає міжнародним стандартам і підлягає обробці різними автоматичними системами зчитування інформації. Ідентифікатори $R O R$ охоплюють випадковий, унікальний і непрозорий (не явний) дев’ятисимвольний рядок і відображаються у вигляді $U R L$-адреси. Наприклад, ідентифікатор ROR Каліфорнійської цифрової бібліотеки: https://ror. org/03yrm 5c26. Для внесення метаданних про організацію розроблено простий і функціональний інтерфейс. Також передбачена можливість редагування та управління записами $R O R$ уповноваженим представником організації, а захищенний доступ до профілю організації здійснюється через дозвільну систему, що унеможливлює несанкціоноване редагування профілю організаціiі. $R O R$ буде відповідати за надання дозволів на керування записами. Набір загальних метаданих про обєкти унифікований і має однакове представлен- 


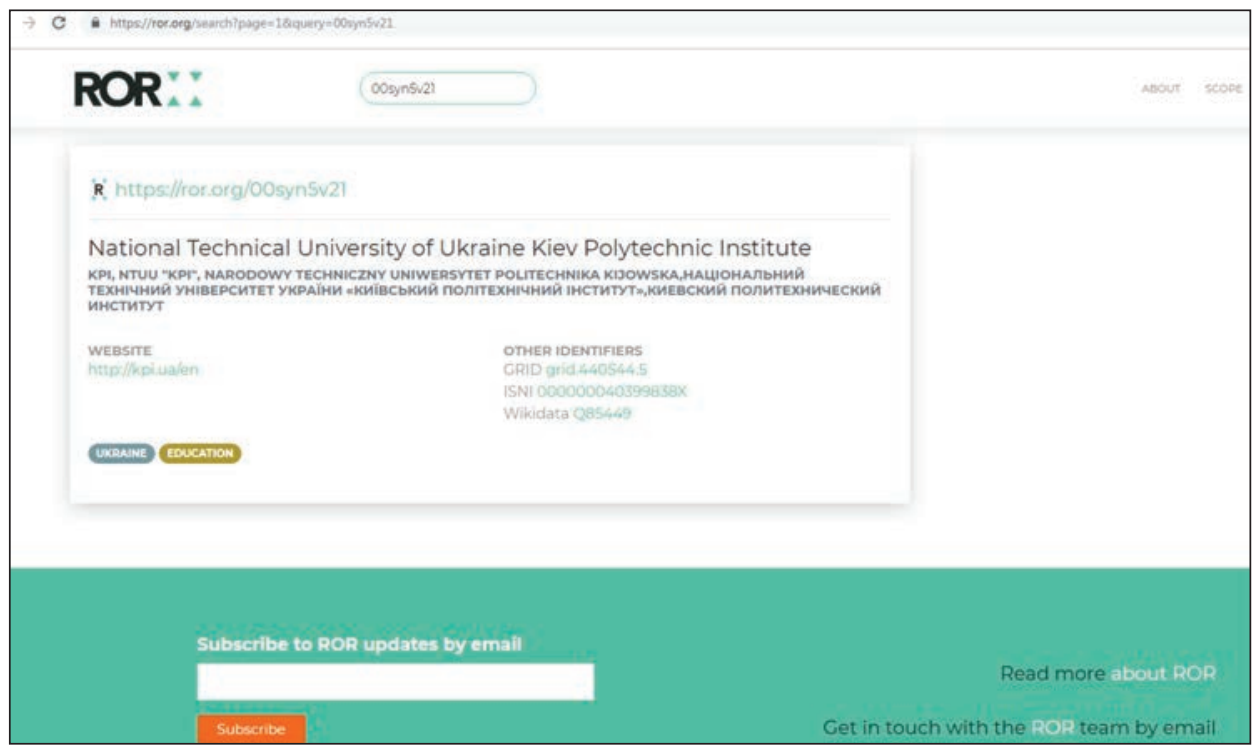

Puc. 7. Персональна сторінка установи у базі даних The Recearch Organization Registry (ROR)

ня. Модель даних $R O R$ складають мінімально необхідні метадані для опису організації, такі як фізичне розташування (штаб-квартира та/ або адреса міста / країни), електронна адреса (URL), постійний ідентифікатор, назва організації офіційною мовою країни походження та, якщо можливо, в латинських символах і походження (джерело надходження інформації). На додаток до необхідних елементів даних, реєстр повинен містити додаткові поля, такі як фізична адреса (латиницею), перехресні переходи до інших ідентифікаторів, вид діяльності організації та вимоги щодо авторського права. Поточна схема заснована на наборі даних GRID, в майбутньому передбачено створення інших полей метаданих відповідно до потреб наукової спільноти.

Існує потреба в керуванні процесами, які стосуються дублювання записів, помилкових записів і взаємозв'язків між записами. Кураторам проекту, можливо, доведеться обирати рішення, які не тільки впливають на метадані, що містяться в записі, або на створення запису, але й установлюють зв'язки між ними за допомогою перенаправлення записів, а також визначати актуальність запису. У випадках дублювання або злиття записи повинні бути перенаправлені на відповідний активний запис. У рідкісних випадках, коли були створені помилкові записи, повинен існувати механізм корегування, який ідентифікує ці записи як помилкові. За необхідності ROR буде взаємодіяти з представником об'єкта, щоб внести зміни до запису, і для всіх змін (тверджень) будуть вказані походження, джерело і час внесення.

$R O R$ почав активно надавати унікальні ідентифікатори організаціям минулого року, і на сьогодні реєстр налічує приблизно 91000 записів про організації. До списку ROR може бути включена будь-яка дослідницька ор- 


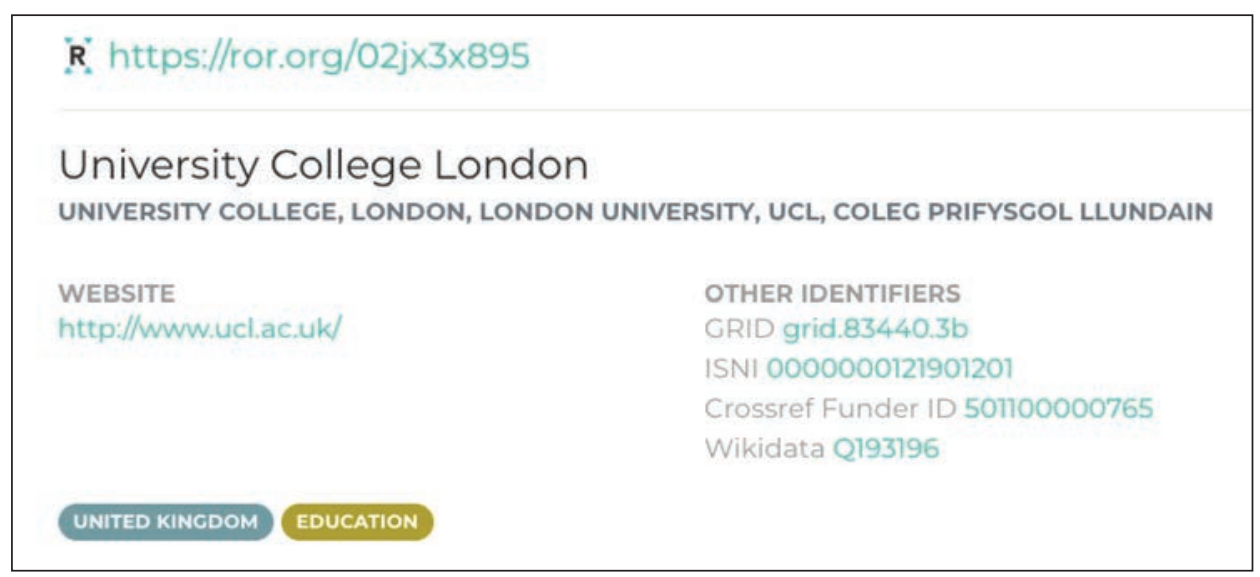

Puc. 8. Приклад результатів параметризованого пошуку бази даних ROR

ганізація, яка провадить дослідження на базі своєї установи чи бере участь у спільних із іншими організаціями дослідженнях, або організація, яка має будь-які формальні відносини з дослідниками, спонсорами чи іншими науковими установами. Для ефективної роботи з реєстром створено зручний пошуковий інтерфейс (https://ror.org/search) (рис. 8).

6. Програма Амбассадор. 2018 року база даних CrossRef започаткувала програму Амбассадор (Ambassadors, https://www.crossref.org/community/ ambassadors/), яка передбачає залучення до співпраці добровольців, добре обізнаних із можливостями і сервісами Crossref і пов'язаних із науковою спільнотою своєї країни. Участь у програмі Амбассадор дає змогу активним користувачам, які вже певний час працюють із Crossref, мати механізм для зворотного зв'язку з базою та отримувати ширшу підтримку.

Команду Амбассадор складають 21 ентузіаст із різних країн світу -Австралії, Бразилії, Колумбії, Індії, Індонезії, Мексики, Нігерії, Перу, Росії, Сінгапуру, Південної Кореї, ОАЕ, США і Венесуели. Посли Crossref - це надійні партнери, які працюють у різних організаціях: бібліотеках, дослідницьких організаціях, видавництвах, університетах. Одночасно із основними професійними обовязками, вони добровільно підтримують наукове співтовариство у своїх регіонах за допомогою постійного спілкування, інтерактивних семінарів і тренингів від Crossref. Крім того, вони беруть участь у тестуванні нових продуктів і сервісів Crossref, мають можливість навчатися різним сервісам і послугам Crossref, мають доступ до пакетів ресурсів (у тому числі і з різними матеріалами), які допомогають їхній діяльності, беруть активну участь у багатьох вебінарах.

Тепер в команді Амбассадор є представник і від України - Анна Данілова, активна учасниця усіх конференцій, автор статей і постійний співавтор методичних рекомендацій щодо упровадження цифрових ідентифікаторів у видавничий процес для періодичних видань Національної академії наук України. 
7. Формат індексу. Структура цифрового ідентифікатора DOI складається з префіксу та суффіксу і виглядає так:

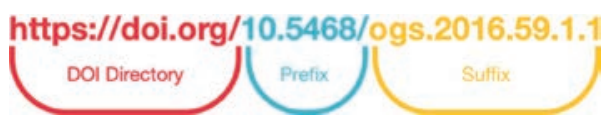

Цифровий ідентифікатор DOI ніколи не змінюється, він постійний, навіть якщо змінюється видавець або організація, що є власником префіксу. У цьому його велика перевага. Два роки тому формат ідентифікатора було змінено - протокол передачі гіпертексту HTTP було замінено на безпечніший і захищеніший HTTPS. Крім того, HTTPS може надавати сигнали Google, які дають сайту, що використовує HTTPS, невелике підвищення рейтингу. Розширення $d x$.doi.org було замінено на doi.org, але цифрові ідентифікатори, які мають частину (до префіксу) http://doi.org/, залишились активними, і немає необхідності ї перереєстровувати.

Цифровий ідентифікатор DOI в електронному вигляді, на сайті журналу, або в друкованій версії журналу, $P D F$-файлі статті, рефераті, або у пристатейному списку літератури, повинен бути представлений у вигляді повного $U R L$-посилання у форматі https://doi.org/10.xxxxx/xxxxx. Йому не повинні передувати позначення «doi:» або «DOI:». Наприклад: https://doi.org/10.5468/ ogs.2016.59.1.1 (рис. 9).

Для користувачів, дослідників, авторів треба скласти рекомендації 3 використання цифрового ідентифікатора і його коректного представлення. Зразок правильного посилання на статтю можна розмістити на сайті журналу. Використання перехресних посилань у пристатейних списках літератури з цифровими ідентифікаторами DOI є обовязковою умовою членства в ор-

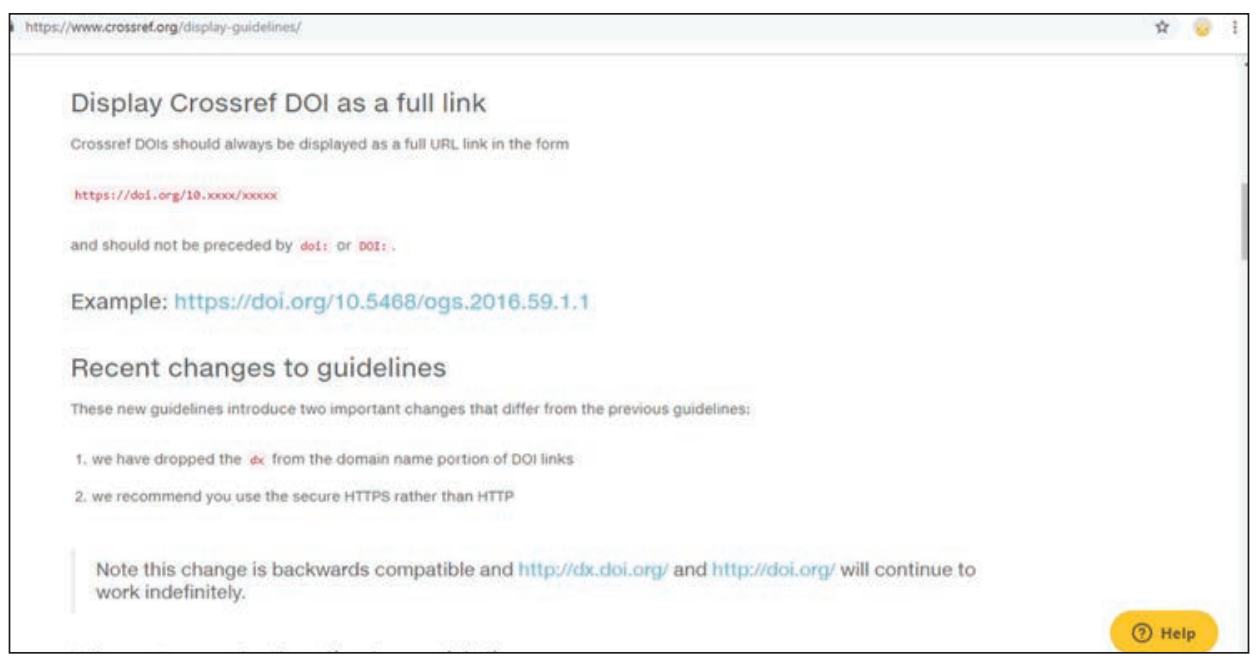

Puc. 9. Рекомендації Crossref стосовно формату відображення ідентифікатора DOI у пристатейних переліках посилань 


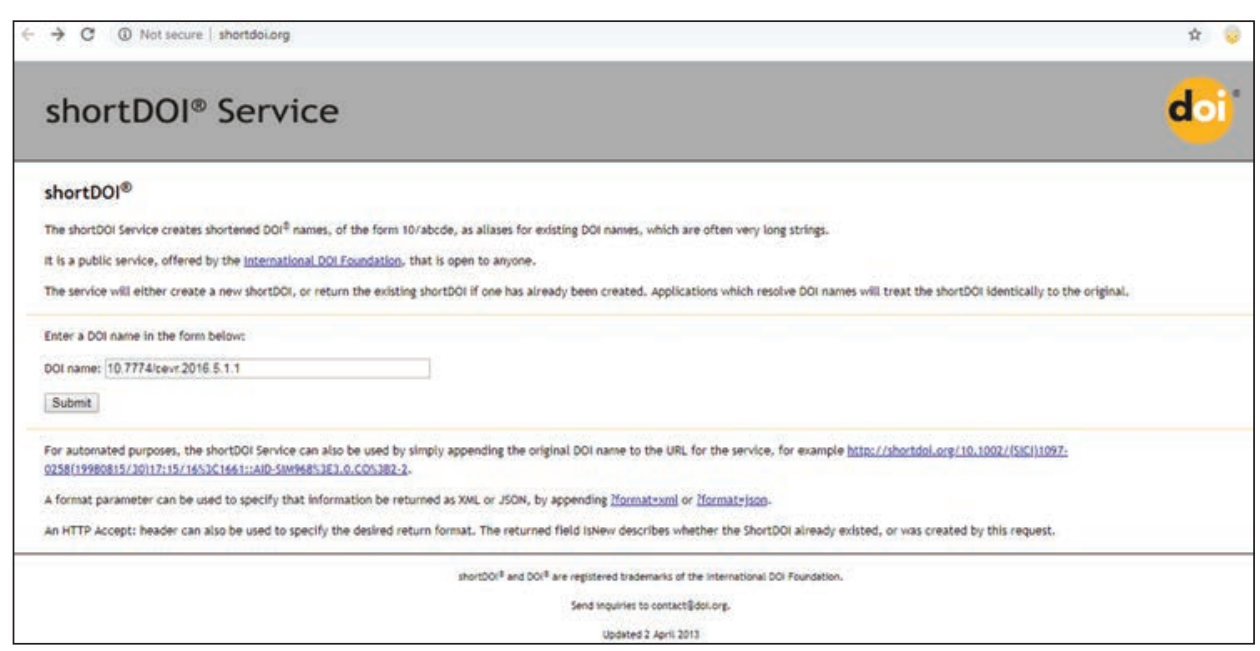

Puc. 10. Приклад формування короткого ідентифікатора DOI за допомогою сервісу ShortDOI

ганізації PILA. DOI можна відображати декільками способами, залежно від стилю публікації. Crossref рекомендує такі формати.

Приклад 1. Використання URL-адреси DOI як постійного (прямого) посилання:

Soleimani N, Mohabati Mobarez A, Farhangi B. Cloning, expression and purification flagellar sheath adhesion of Helicobacter pylori in Escherichia coli host as a vaccination target. Clin Exp Vaccine Res. 2016 Jan; 5 (1): 19-25. https://doi.org/10.7774/cevr.2016.5.1.19

Приклад 2. Відображення тексту «Crossref» з прихованим посиланням на статтю:

Galli, S.J., and M. Tsai. 2010. Mast cells in allergy and infection: versatile effector and regulatory cells in innate and adaptive immunity. Eur. J. Immunol. 40: 1843-1851. Crossref

Такий спосіб не дозволяє бачити значення цифрового ідентифікатора і скопіювати його для подальшого використання.

Приклад 3. Короткий формат індексу ShortDOI [10]. Міжнародний Фонд DOI створив сервіс ShortDOI (http://shortdoi.org/) як загальнодоступну систему, яка створює короткі форми для $D O I$ (рис. 10).

DOI можуть бути занадто довгими, тому цей сервіс має на меті скорочення URL-посилання. Наприклад, для DOI https://doi.org/10.7774/cevr.2016.5.1.1 можлива скорочена форма (https://doi.org/bwfc). Для кожного DOI створюється тільки один ShortDOI, і цей ShortDOI надає такі самі можливоті, що і DOI.

ShortDOI широко не використовують і самі по собі вони не є фактичними DOI, а лише модифікованими варіантами. Їх використання може призвести до помилок. Тому рекомендовано прагнути не застосовувати даний сервіс, а будувати логічні зрозумілі короткі DOI.

Основний висновок із викладеного вище такий - цифровий ідентифікатор DOI в усіх випадках повинен відображатися як посилання, тому що це не звичайний ідентифікатор, і постійне посилання на сторінку, з якою він пов'язаний. Користувачі легко можуть їх скопіювати для подальшої роботи. Крім того, не всім відомо, що таке DOI, але всі знають, що таке посилання. 
Важливо прописувати цифровий ідентифікатор DOI на домашній сторінці статті. Як тільки метадані статті будуть зареєстровані в депозитарії Crossref, користувачі зможуть отримати ідентифікатори і створити з ними посилання на сторінку відповідної статті. Домашня сторінка кожної статті має містити такі метадані: цифровий ідентифікатор DOI цієї статті (відображаєтся як $U R L$-адреса), правильний опис-посилання на статтю (скорочена англомовна назва журналу відповідно до ISSN, рік виходу, том, номер, сторінковий інтервал статті), прізвища авторів, назви установ, де вони працюють, назву статті, анотацію (резюме) до статті, ключові слова, пристатейні списки літератури, механізм переходу на повнотекстову версію статті (наприклад у форматі $P D F)$ (рис. 11).

Детальну інформацію про користування системою цифрових ідентифікаторів DOI та підготовку сайту наукового періодичного видання можна знайти на інтернет-сайті Передплатного агентства «Укрінформнаука» (рис. 12).

База даних Crossref діє як центр обміну інформацією, об’єднуючи і пов'язуючи контент своїх постійних партнерів в одну величезну інформаційну платформу. Результатом $є$ наукова комунікаційна інфраструктура, яка забезпечує обмін новими ідеями і знаннями. Правильно зареєстровані, постійно чинні і коректно реалізовані цифрові ідентифікатори DOI у будь-який момент часу будуть приводити читачів до того контенту, який вони шукають, включаючи інтернет-сторінки наших наукових журналів. За умови коректного подання формату цифрових ідентифікаторів DOI будь-хто будь-



Puc. 11. Приклад коректної домашньої сторінки статті (https://doi.org/10.1364/ JOSAB.1.000354) 

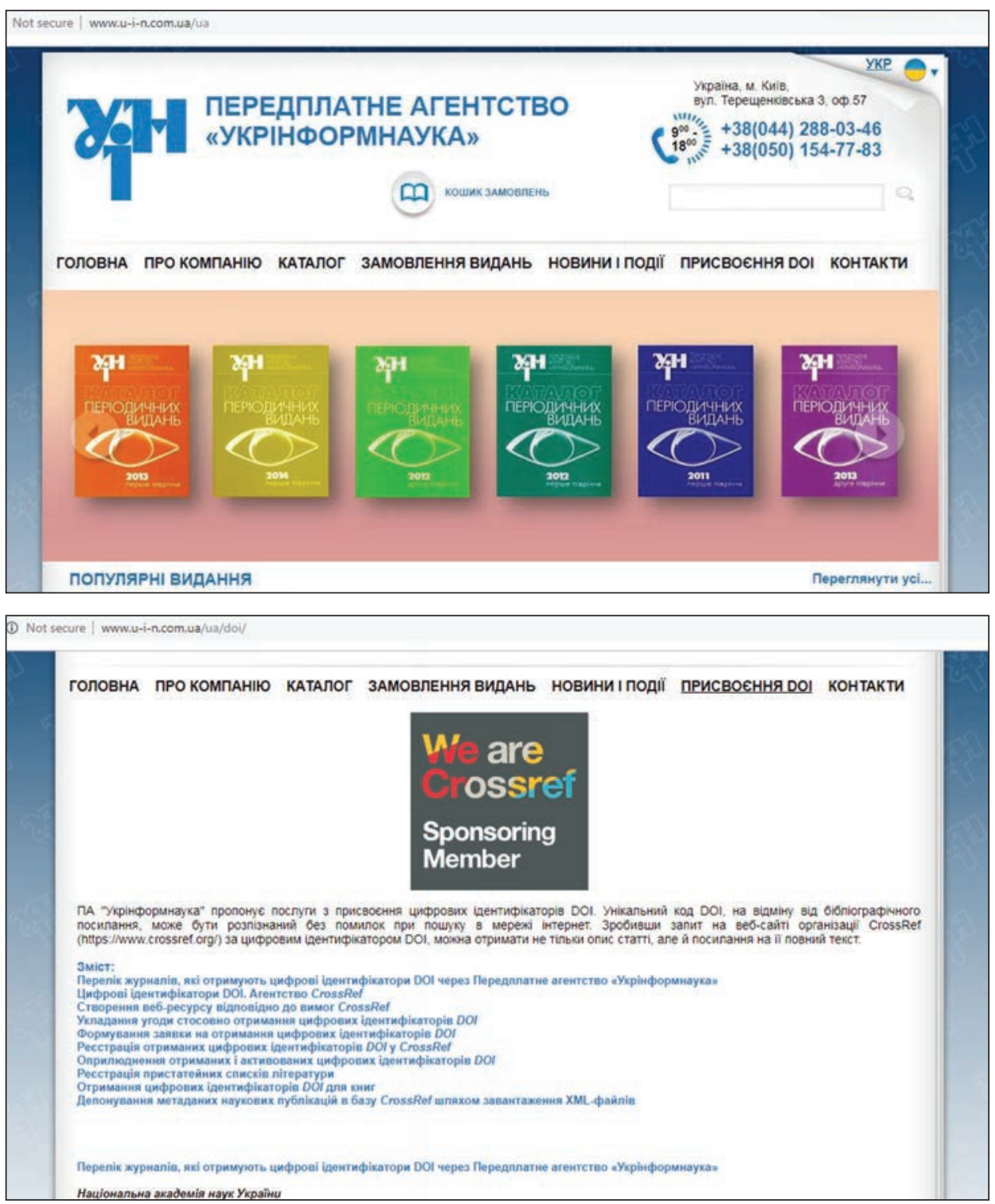

Puc. 12. Сторінки сайту Передплатного агентства «Укрінформнаука»: початкова (угорі) та з інформацією про доступні сервіси Crossref (унизу)

коли може скопіювати і поділитися з колегами посиланням на наші наукові публікації [11]. Це створює для користувачів можливість за посиланням DOI зі списку літератури опублікованої роботи вільно переходити до розташованного в інтернеті повнотекстового документа на платформі наукової публікації, створюючи мережеву інфраструктуру, яка розширює наукові зв’язки у світовому інформаційному просторі. 


\section{СПИСОК ВИКОРИСТАНИХ ДЖЕРЕЛ}

1. Price D.J. de S. Little Science, Big Science. New York: Columbia University Press, 1963. 301 p.

2. Яцків T.M. Критерії оцінки наукового журналу. Цифровий ідентифікатор DOI як критерій оцінки наукового журналу. Наука України у світовому інформаційному просторі. Вип. 14. Київ, 2017. С. 106-113. https://doi.org/10.15407/akademperiodyka.337.106

3. Яцків Т.M., Данілова А.Д. Надання цифрових ідентифікаторів DOI як один із заходів покращення видимості наукового журналу. Наука України у світовому інбормаційному просторі. Вип. 15. Київ, 2018. С. 55-65. https://doi.org/10.15407/ akademperiodyka.372.055

4. CrossRef. [Electronic resource]. https://www.crossref.org/ (дата звернення: 30.05.2019).

5. Яцків Т.M. Цифрові ідентифікатори DOI для наукових публікацій: принцип роботи та можливості бази даних агентства CrossRef. Наука України у світовому інформаційному просторі. Вип. 13. Київ, 2016. С. 73-79. https://doi.org/10.15407/ akademperiodyka.321.073

6. Ukrinformnauka. URL: http://u-i-n.com.ua/en/ (дата звернення: 30.05.2019).

7. Данілова А.Д. Користування додатковими сервісами бази даних CrossRef. Наука України у світовому інформаційному просторі. Вип. 14. Київ, 2017. С. 114-120. https:// doi.org/10.15407/akademperiodyka.337.114

8. Данілова А.Д. Підготовка інтернет-сторінки наукового видання з метою отримання цифрових ідентифікаторів DOI, процес реєстрації індексів, підготовка пристатейних списків літератури та їх реєстрація. Наука України у світовому інформаційному просторі Вип. 13. Київ, 2016. С. 80-89. https://doi.org/10.15407/akademperiodyka.321.080

9. The Recearch Organization Registry (ROR). URL: https://ror.org (дата звернення: 23.05.2019).

10. ShortDOI. URL: http://shortdoi.org/ (дата звернення: 22.05.2019).

11. Радченко A.I., Яцків T.M. Система цифрових ідентифікаторів DOI для журналів НАН України. Наука України у світовому інформаційному просторі. Вип. 11. Київ, 2015. C. 18-23. URL: http://akademperiodyka.org.ua/uk/books/science_ukraine_gis/11/3 (дата звернення: 30.05.2019).

Надійшла 30.07.2019

\section{REFERENCES}

1. Derek J. de Solla Price. Little Science, Big Science. Columbia University Press, New York, 1963. $301 \mathrm{p}$.

2. Yatskiv T.M. Evaluating standards for scientific journals. DOI as an evaluation criterion of a scientific journal. Science of Ukraine in the Global Information Space. 2017. 14: 106-113. https://doi.org/10.15407/akademperiodyka.337.106 [in Ukrainian].

3. Yatskiv T.M., Danilova A.D. DOI assignment as one of factors of raising a scientific journal's visibility. Science of Ukraine in the Global Information Space. 2018. 15: 55-65 [in Ukrainian].

4. CrossRef. [Electronic resource] https://www.crossref.org/

5. Yatskiv T.M. The digital object identifier (DOI) for publications: the principles and opportunities of the Crossref Agency database' work. Science of Ukraine in the Global Information Space. 2016. 13: 73-79. https://doi.org/10.15407/akademperiodyka.321.073 [in Ukrainian].

6. Ukrinformnauka. [Electronic resource]. http://u-i-n.com.ua/en/

7. Danilova A.D. Using additional services of the CrossRef database. Science of Ukraine in the Global Information Space. 2017. 14: 114-120. https://doi.org/10.15407/akademperiodyka.337.114 [in Ukrainian].

8. Danilova A.D. Preparing web resources of scientific publications for obtaining digital object identifiers (DOIs), DOI registration process; preparation and depositing of reference lists. 
Science of Ukraine in the Global Information Space. 2016. 13: 80-89. https://doi.org/10.15407/ akademperiodyka.321.080 [in Ukrainian].

9. The Recearch Organization Registry (ROR). URL: https://ror.org

10. ShortDOI. URL: http://shortdoi.org/

11. Radchenko A.I., Yatskiv T.M. DOI Digital Identifier System for the National Akademy of Sciences of Ukraine journals. Science of Ukraine in the Global Information Space. 2015. 11: 18-23. URL: http://akademperiodyka.org.ua/uk/books/science_ukraine_gis/11/3 [in Ukrainian].

Received 30.07.2019

\section{T.M. Yatskiv}

Subscription Agency «Ukrinformnauka»

A.D. Danilova

Subscription Agency «Ukrinformnauka», CrossRef Ambassador

INCREASING THE NUMBER OF REFERENCES TO SCIENTIFIC PUBLICATIONS: SEVEN STEPS TOGETHER WITH CROSSREF

The main topics of the article are the issue of increasing the visibility of scientific periodicals in the international information space and raising the number of References to them using cross-linking. Different CrossRef database tools and services, such as Metadata Manager BETA, Cited-by, the newly created registry of Funders to join Crossref as members are described. The importance of the Initiative for Open Citations program, whose main purpose is to increase access to citations of scientific publications, is demonstrated. The Recorder Organization Registry (ROR) registry features are described.

Keywords: Web of Science and Scopus international scientometric databases, DOI digital identifiers, CrossRef Agency, Initiatives for Open Citations programs, Metadata Manager BETA, Cited-by service, database, search engine. 